\title{
河口埋立形状が洪水流出流の流動構造に 及活す影響について
}

中辻啓二*・山見晴三**. 室田 明***

\section{1. まえがき}

近年，大阪湾・東京湾をはじめとした大都市周辺にお いて埋立がさかんに行われており, 河口付近の内湾形状 は年々変化してきている. 河口前面の埋立は河口の開口 度を狭めて河川水の排出を妨げ, 河口に抢ける過剩な水 位上昇等を引き起こす恐れがある.とくに，洪水時にお ける河口水位は不等流計算の下流端条件を与兄, 河川の 治水・防災計画を策定する上で重要な量である. しかし ながら，現在のところこれらに関する知見は少ない，

河口に怙注る水位上昇は数 $\mathrm{cm}$ のオーダーであり, 水 理実験・現地観測における計測は非常に困難である。一 方, 数值実験は河口形状の数 $\mathrm{km}$ の長さスケールと, 河 口水位の数 $\mathrm{cm}$ の長さスケールとを同精度で正確に捉え ることを可能とするものである. 從来, 三次元数值モデ ルとしては渦動粘性・拡散係数を用いる0方程式モデル が一般的に用いられている. しかし，係数値の設定には 水理実験に基づく経験則に頼らざるを得ない，そのため 淡水と塩水が混ざり合う河口付近の複雑な三次元流動を 正確に再現できるが否か，さらに工学的判断を可能とす る精微な情報を提供できるか否かは，寲問である.

本研究では乱流輸送量を客観的に評価できる $k-\varepsilon モ$ デルを三次元河川プルームの数值実験に適用し，水理実 験結果（西田，1980）や0方程式モデルを用いた数值実 験結果（湯浅ら，1989）との比較からその適用性を検討 する.ささに，洪水時を想定して河口開口度を変化させ た数值実験を行い, 埋立地形の流動・密度構造に及ぼす 影響について榆討を行った。

\section{2. 三次元 $k-\varepsilon$ 乱流モデル}

\section{（1）基礎方程式}

静水圧近似・Boussinesq 近似を用いるならば，河川プ ルームの三次元流動を支配する連続方程式, 運動方程式 ならびに密度偏差 $\Delta \rho$, 乱流エネルギー $k$, およびェネ

* 正会員 工博 大阪大学助教授 工学部土木工学科

** 学生員大阪大学大学院工学研究科

*** 正会員工博 大阪産業大学教授 工学部土木工学科
ルギー逸散率 $\varepsilon$ の輸送方程式は次式で表現される.

$$
\begin{aligned}
& \frac{\partial U_{i}}{\partial x_{i}}=0 \quad(i=x, y, z) \\
& \frac{D U}{D t}=-\frac{1}{\rho_{s}} \frac{\partial P}{\partial x}+\frac{\partial}{\partial x_{i}}\left(\nu_{i} \frac{\partial U}{\partial x_{i}}\right) \\
& \frac{D V}{D t}=-\frac{1}{\rho_{s}} \frac{\partial P}{\partial y}+\frac{\partial}{\partial x_{i}}\left(\nu_{i} \frac{\partial V}{\partial x_{i}}\right) \\
& 0=-g-\frac{1}{\rho_{s}} \frac{\partial P}{\partial z} \\
& \frac{D \Delta \rho}{D t}=\frac{\partial}{\partial x_{i}}\left(K_{i} \frac{\partial \Delta \rho}{\partial x_{j}}\right) \\
& \frac{D k}{D t}=\frac{\partial}{\partial x_{j}}\left(\nu_{j} \frac{\partial k}{\partial x_{i}}\right)+\frac{\partial}{\partial z}\left(\frac{\nu_{z}}{\sigma_{k}} \frac{\partial k}{\partial z}\right) \\
& +P_{\nu}+G-\varepsilon \\
& \frac{D \varepsilon}{D t}=\frac{\partial}{\partial x_{j}}\left(\nu_{j} \frac{\partial \varepsilon}{\partial x_{j}}\right)+\frac{\partial}{\partial z}\left(\frac{\nu_{z}}{\sigma_{\varepsilon}} \frac{\partial \varepsilon}{\partial z}\right) \\
& +\frac{\varepsilon}{k}\left(c_{1 \varepsilon} P_{\nu}-c_{2 \varepsilon} \varepsilon+c_{3 \varepsilon} G\right)
\end{aligned}
$$

ここに,

$$
P_{\nu}=\nu_{z}\left[\left(\frac{\partial U}{\partial z}\right)^{2}+\left(\frac{\partial V}{\partial z}\right)^{2}\right], G=\frac{g}{\rho} K_{z} \frac{\partial \rho}{\partial z} .
$$

座標は河口の中心軸の平均水面に原点をとり, 流下方 向に $x$ 軸, 横方向に $y$ 軸, 鉛直上向きに $z$ 軸とする. $U, V, W$ は各方向の流速成分, $P$ は圧力, $\nu_{i}$ 㐨よび $K_{i}$ は各方向の渦動粘性・拡散係数である. 密度 $\rho\left(=\rho_{s}-\right.$ $\Delta \rho)$ は塩分濃度と線形関係にあると仮定している． $\rho_{s}$ は 海水密度, $\Delta \rho$ は密度差である. 圧力 $P$ は式 $(4)$ を水表 面 $(z=\eta)$ から任意の水深をで積分することにより求め る. したがって, 水平方向圧力勾配 $d P / d x_{j}$ は水面勾配 と密度勾配 $d \rho / d x_{j}$ の関数として表される. 三次元密度 流数值モデルは前報(室田ら，1989）と本質的に同じもの を採用した。 また， $k, \varepsilon$ の翰送方程式中の係数 $c_{1 \varepsilon,} c_{2 \varepsilon}, c_{3 s}$, $\sigma_{k}, \sigma_{\varepsilon}$ は慣用値 $1.44 ， 1.92 ， 1.0 １ .0 １ .3$ を用いた.

$k-\varepsilon$ モデルでは鉛直方向の渦動粘性係数 $\nu_{z}$ は $k$ 打 よび $\varepsilon$ の輸送方程式に基づき, $\nu_{z}=0.09 k^{3 / 2} / \varepsilon$ にり 算出される. 乱流シュミット数 $\sigma_{t}\left(=\nu_{z} / K_{z}\right)$ につい は Munk \& Anderson 式 (1948)を採用した。 また, 水平方向の両係数は浮力の影響が少ないといら従来の考 方方に基づき，噴流の理論值 $\nu_{H}=K_{H}=0.0256 U_{0} B_{0}$ を 
全計算領域で与える. $U_{0}, B_{0}$ は河口での流速, 河口半 幅である。

一方, 0 方程式モデルでは一定値の $\nu_{z}$ と $K_{z}(=$ $\left.0.0256 U_{0} B_{0}\right)$ を与兄, 成層化の 影響は成層化関数で補 正した. 成層化関数として， $\nu_{z}, K_{z}$ に対してそれぞれ Webb 式 (1970), Munk \& Anderson 式 (1948)を用い た.また, 水平方向の両係数は $k$ - $\varepsilon$ モデルと同様に一 定值とした.

\section{（2）モデル海域}

モデル海域は河道部と連結させた海域の河川中心軸か ら片側半領域を想定する. 河道部は長さ $60 \mathrm{~cm}$, 半幅 $B_{0}=4 \mathrm{~cm}$, 上流端水深 $H_{0}=2.0 \mathrm{~cm}$, 河口水深 $H_{m}=$ $3.0 \mathrm{~cm}$, 海域部は長さ $350 \mathrm{~cm}$, 半幅 $150 \mathrm{~cm}$, 水深 3.6 $\mathrm{cm} \sim 24.0 \mathrm{~cm}$ である. これは北大での水理実験（西田， 1980）を模擬したものである. 計算領域は河道部で $x$, $y, z$ 方向にそれぞれ $60,4,4 \sim 6$, また海域部で 30,25 , $7 \sim 14$ の格子網で構成されている. 離散化間隔は $\Delta x=$ $1.0 \sim 66.2 \mathrm{~cm}, \Delta y=1.0 \sim 19.3 \mathrm{~cm}, \Delta z=0.5 \sim 5.5 \mathrm{~cm}$ で ある. 離散化間隔 $\Delta t$ は計算の安定性を考慮して 0.01 秒 とした。

境界采件は陸岸抢よび底面で non-slip 条件, 開境界 で水位ならびに速度勾配が一定，また全ての境界で密度 流束が 0.0 とした.

放流口は河道部全断面とした. 放流条件は上流端放流 口で流速 $U_{r}=Q_{r} / B_{0}\left(H_{r}+\eta\right)$, 密度差 $\Delta \rho$, 乱流エネル ギー $k_{r}=0.025 U_{r}^{2}$ ならびにェネルギー逸散率 $\varepsilon_{r}=$ $k_{r}{ }^{3 / 2} / H_{r}$ を断面一様淿与兄た.

\section{3. 計 算結 果}

\section{（1） $k-\varepsilon$ モデルと 0 方程式モデルの比較}

計算条件は北大での水理実験条件を参考倣流流量

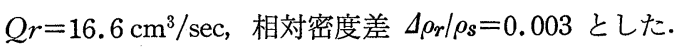

図一1 は中心軸上の表層に和ける $\nu_{z}$ の流下方向变化 を示す. $k-\varepsilon モ テ ゙ ル の ~ \nu_{z}$ は 0 方程式モデルに比べて, 少し大きな值となっている、これは上流端での $k r$ 抒よ び $\varepsilon_{r}$ の設定值が噴流で得られる值よりも少し大きかっ たことに原因していると考穴られる.上流端で与兄られ た $k$ 特よび $\varepsilon$ が河道内では鉛直下方に拡がって輸送さ れるために, ע の值は流下方向に減少していく傾向にあ る. しかし, 河口に近づくと, 浮力の影響を受けて $k$, $\varepsilon$ が上方偷送され，表層での $\nu_{z}$ の值は大きくなる. 河口を出ると, $k$ や $\varepsilon$ は表 層を水平方向に拡がるため に $\nu_{z}$ の值は流下方向に急速に減少していく. 一方, 0 方程式モデルでは全断面で一定值を与えた $\nu_{z}$ が成層化 関数により減少するのみである. そのため表層での עz の值は流下方向に概ね一定值をとる. 図一1 の河道内で 観られる עzの增減の繰り返しは底面の不連続に伴う計

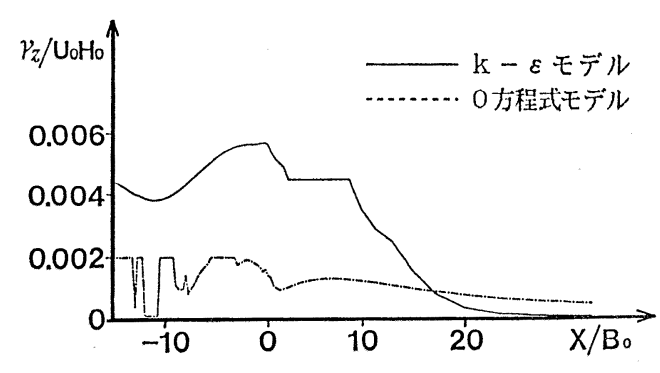

図一1 中心軸上の $\nu_{z}$ の流下方向变化
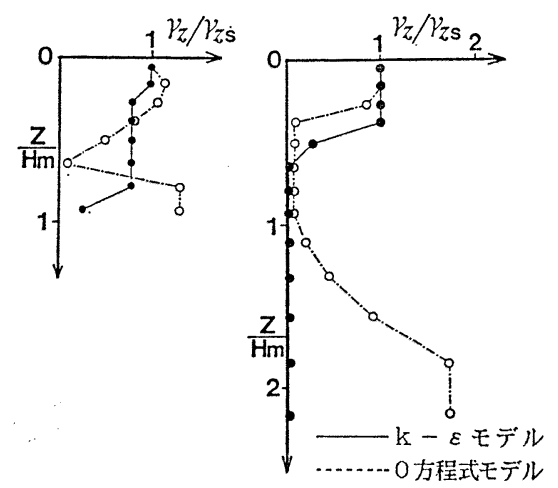

(a) $\mathrm{x} / \mathrm{B}_{0}=0.125$

(b) $\mathrm{x} / \mathrm{B}_{0}=3.538$

図一2 中心軸上の $\nu_{z}$ の鉛直方向分布

算䛊差の現れであると考えられる.

图一2 は $x / B_{0}=0.125,3.538$ の断面での中心軸に打 ける $\nu_{z}$ の鉛直方向分布を示す. $k-\varepsilon$ モデルでは $\nu_{z}$ の 值は水表面から鉛直下方に連続的に減少する現象を良好 に再現している. 一方, 0 方程式モデルでは下層部付近 で成層化関数による成層効果があまり効かず， $\nu_{z}$ は一 定值に近い值を保持する. とも $k$ - モデルの方が大きいようである.

図一3 は密度フルード数 $F d$ の水平分布を示す. 上図 に $k-\varepsilon$ モデルによる計算結果, 下図に北大での水理実 験結果（西田，1980）を示した．数值実験では密度差が 初期密度差の $2 \%$ となる水深で定義した淡水層厚 $H_{u}$ と

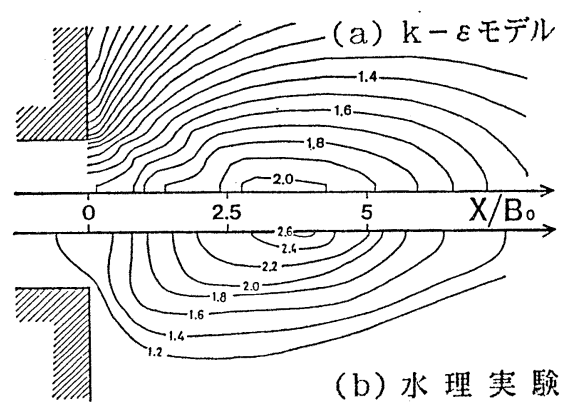

図-3 密度フルード数 $F d$ の水平方向分布の比較 
表層の最大流速 $U_{s}$ を用いて $F d$ 数を算出した. 水理 実験では染料の可視化に基づいた淡水層厚を用いた． $k$ $-\varepsilon$ モデルでの $F d$ 数は水理実験結果に比べて全体的に 小さな值となる. しかし, $k-\varepsilon$ モデルの結 果は既報の 0 方程式モデルの結果（湯浅ら，1989）と比較して Fd 数の最大となる位置や $F d$ 数の分布特性をより良好に予 測しているのが分かる.

この結果得られる $k-\varepsilon$ モデルによる河口での淡水層 厚 $H_{u}$ は $2.12 \mathrm{~cm}\left(H_{u} / H_{m}=0.76\right)$, 河口密度フルード 数 $F d_{0}$ は 0.99 であった. また, 河口水位上昇量 $\eta_{0}$ は $0.0051 \mathrm{~cm}$ である. この值は淡水層厚の $0.239 \%$ であ り，0方程式モデルによる計算結果の $0.241 \%$ とほぼ 同じであった.

以上の計算結果から三次元河川プルームの流動解析に おいて，k一モモデルが乱流輸送量を客観的に評価でき， 河川プルームの流動をより正確に再現できることを確認 できた.

\section{（2）河口形状の変化にともなう流動構造の変化}

本節では河口開口度を 90 度から 5 度まで 4 段階に変光 た計算を実施し，流動構造や水位上昇の違いを考察す る. 上流端条件は放流流量 $Q_{r}=60.1 \mathrm{~cm}^{3} / \mathrm{sec}$, 相対密度 差 $\Delta \rho_{r} / \rho_{s}=0.022$ である.

図一4 は中心軸上の水位上昇量 $\eta$ の流下方向変化を 示す. 河口開口度 90 度に和ける岸・板倉 (1985) の水理 実験結果も併せて示す. 開口度90度の計算結果は水理実 験結果と比皎して河口近傍では注淁妥当な值が得られて いるが，河口を出た後の低減は少し大きい，河口での $\eta_{0}$ は河口水深 $3.0 \mathrm{~cm}$ に対して開口度 90 度の場合 0.055 $\mathrm{cm}$ である．その值は流速・密度を矩形として静水圧近 似に基づいて求めた值 $0.061 \mathrm{~cm}$ や流速と密度に相似形 分布を仮定した岸・板倉（1985）の理論値 $0.058 \mathrm{~cm}$ と 比べて少し小さい, 一方, 河口開口度が30度, 11 度, 5 度と狭まるにつれて水位上昇量は $0.057 \mathrm{~cm}, 0.057 \mathrm{~cm}$, $0.061 \mathrm{~cm}$ とわずかながら上昇する。 これらの值は開口 度90度の場合に対してそれぞれ 3.6\%，3.6\%，10.9\% の上昇率であった. 開口度が 5 度程度になると, 河口で の水位上昇が特徵的に認められることになる.この傾向 は水面形の流下方向変化にも現れており, 開口度 5 度の 場合は他の計算結果と比較して少し特異である.

この傾向を視覚的に捉えるために河口付近 $(-60 \mathrm{~cm}$ $\leqq x \leqq 100$ _cm, $0 \leqq y \leqq 45 \mathrm{~cm}$ ) の水面形を三次元的に表示 したのが 図一5 である.90度の場合, 水面形は河口か ら放射状に拡がって打り, 河口付近での水面勾配が著し く大きい，開口度の大きい30度の埋立では，90度の水面 形と類似している。しかしながら，11度，5度では埋立 側壁面の影響を受けて，横方向への拡がりが制限される

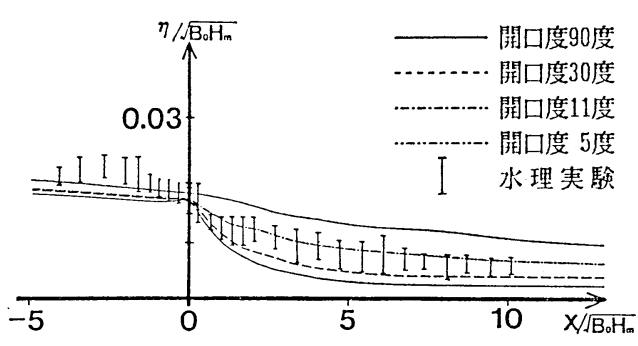

图一4 中心軸上の水位上异量 $\eta$ の流下方向変化
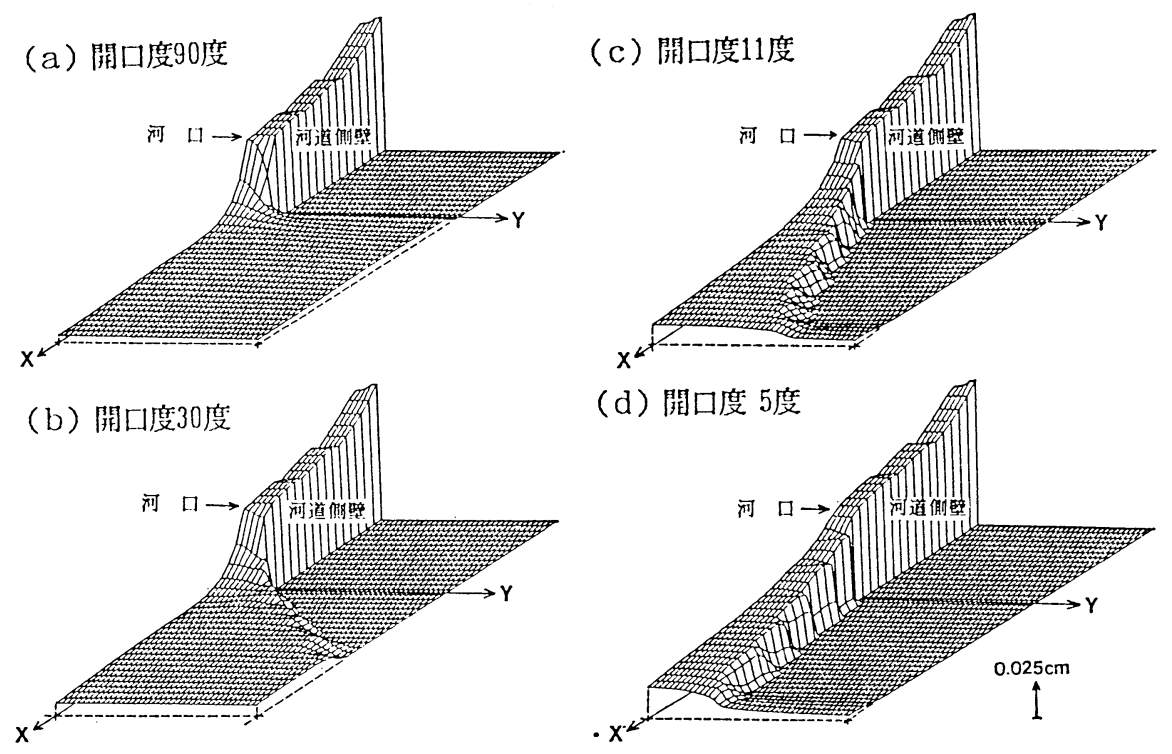

図一5 河口開口度による水面形の比較 
ために，水面勾配は緩やかで，水面形は流下方向に徐々 に低下するようになる。

つぎに，図一6 は水面下 $0.25 \mathrm{~cm}$ での等密度差線 $(\Delta \rho /$ $\left.\Delta \rho_{r}\right)$ ・流速ベクトル $\sqrt{U^{2}+V^{2}}$ の水平方向分布を示す. 90度の場合, 河川水は河口からほぼ 30 40 度で拡がる のは既往の結果(Murota et al, 1989) と同じである. 30 度, 11 度拉よび 5 度と開口度が狭まるにつれて, 埋立側 壁面の影響が徐々に大きくなり，90度の場合と比較して 流下方向への拡がりが大きくなる傾向にある.

図一7 は $x / B_{0}=10$ での鉛直断面 $\left(0 \leqq y / B_{0} \leqq 15\right.$, $-1.1 \leqq z / H_{m} \leqq 0 ）$ に抢ける等 密度差線・流速ベクトル を示す.また，水位上昇量は鉛直方向長さスケールに対 して 100 倍に拡大して示した. 開口度90度の計算結果に は密度美が初期密度差の $2 \%$ となる密度界面付近を境界 にして上層部では外縁方向の流れが，下層部では中心軸 に向から流れが認められる. とくに，水表面直下では外 緑向きの流速が $y / B_{0}$ の増大とともに大きくなる特徵が

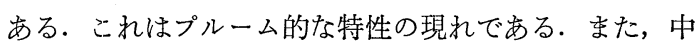
心軸付近では鉛直上向きの流れ，いわゆる連行が生じて いる．30度の場合には流動に及ぼす埋立側壁面の影響は 小さく，90度の場合とほぼ同じ傾向である. 一方，11 度, 5 度の埋立の場合には埋立側壁面によって横方向へ の拡がりが制限され, 側壁面近くで下向きの流れが起こ っている. その結果, 循環が鉛直断面内で起こっている のが特徽的である.

そこで, 淡水層厚 $H_{u}$ の流下方向変化を示したのが 図一8 である. 開口度90度ならびに30度では $H_{u}$ は河 口を出た後に急減し，その後は一定值を保っている。一 方, 開口度 11 度, 5 度では河口付近での急減はみられ
ず，横方向への拡がりが埋立瞧壁面で制限された割合だ け，90度，30度の場合に比べて鉛直方向への拡がりが大 きい.このようなことから, 河口付近での $H_{u}$ の急減は 断面急拡大の影響の現れであると推定される. 5 度の場 合に $H_{u}$ が $x / B_{0}=25$ 付近で再び減少するのは, 図一6 にみられるように埋立の先端で横断面積が急增大する影 響である。
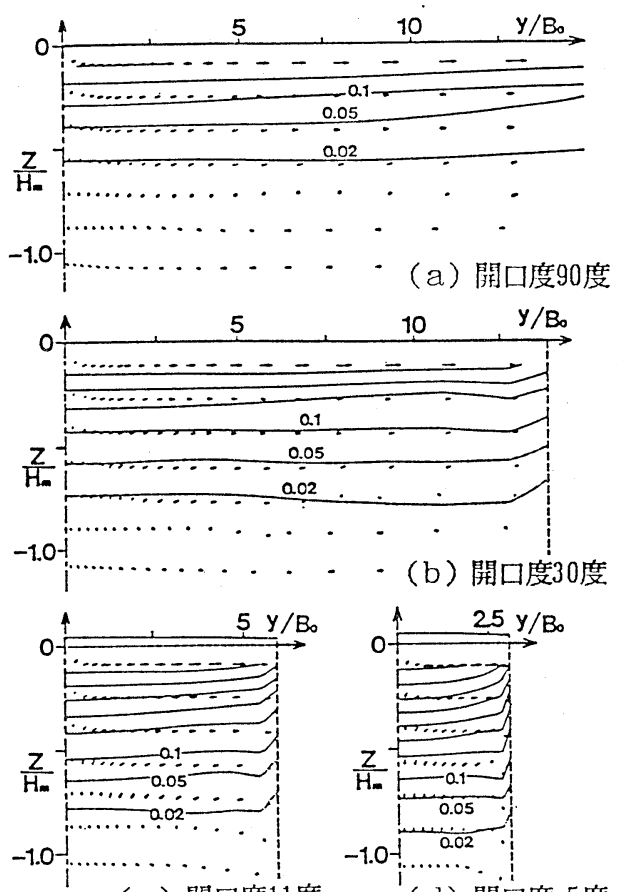

(c) 開口度11度

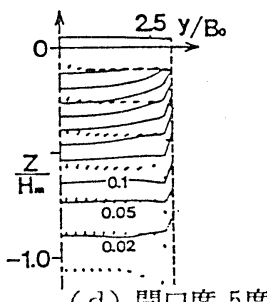

(d) 開口度 5 度

図一7 開口度による断面内流動特性の比較
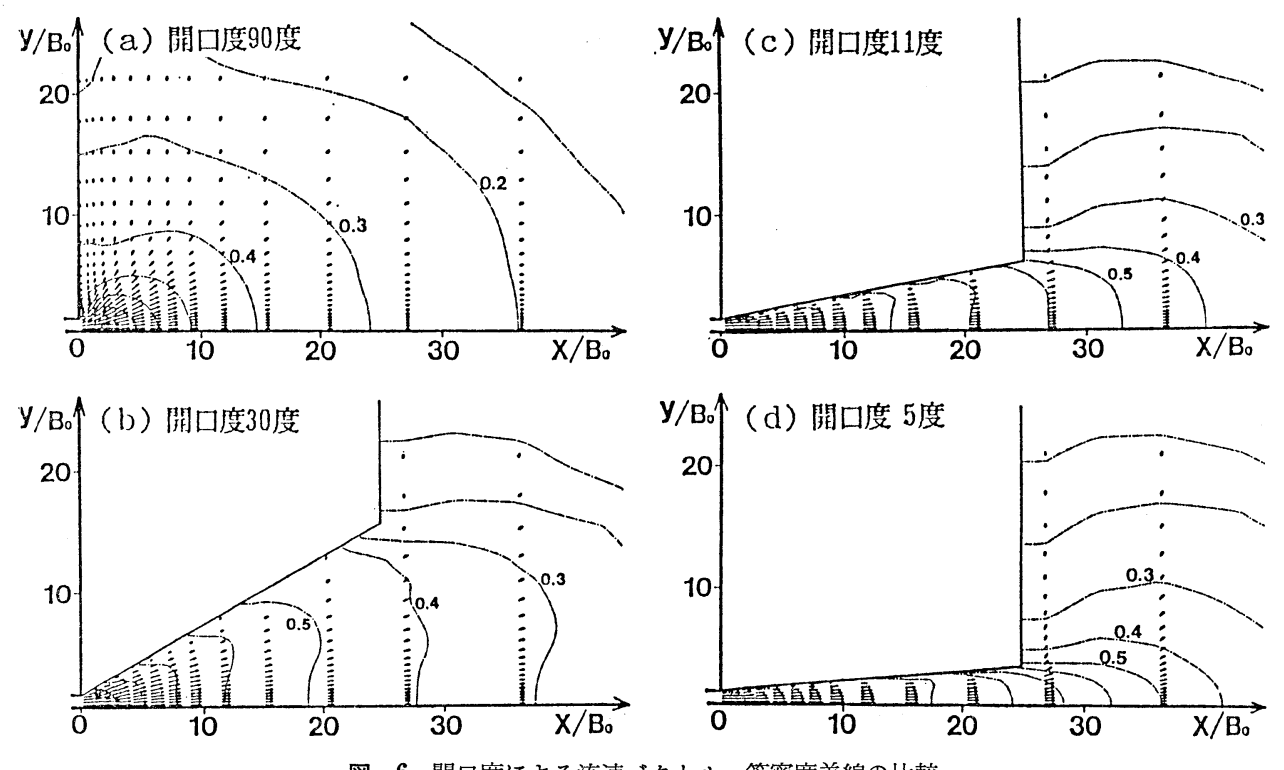

図一6 開口度による流速べクトル・等密度差線の比較 


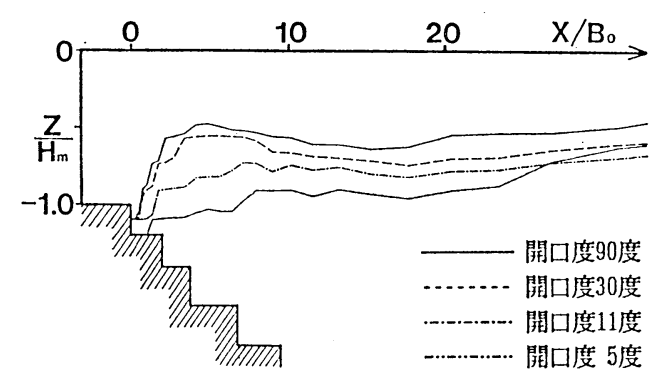

図一8 中心軸上の淡水層厚 $H_{u}$ の流下方向変化

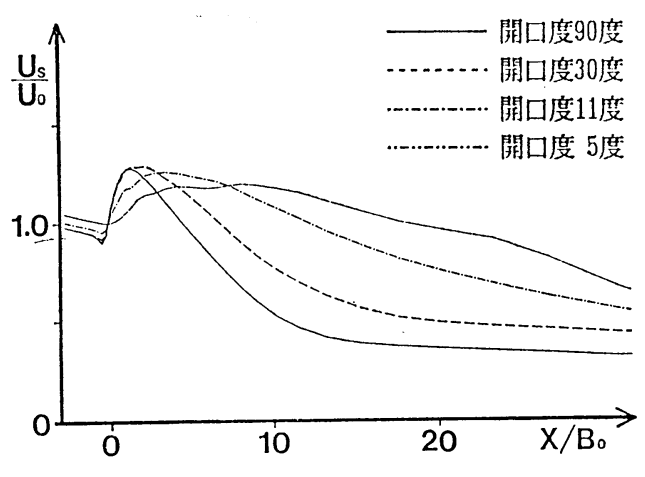

図一9 中心軸上の水表面流速 $U_{s}$ の流下方向变化

図一9 は水面下 $0.25 \mathrm{~cm}$ での中心軸上の流速 $U_{s}$ の 流下方向変化を示す. 開口度 90 度, 30度の場合には河口 付近に打いて流動が一時的に加速される河川流出流特有 の一次加速現象が顕著に現れている. そのときの最大流 速は河口での流速の約1.27倍にも相当する. 一方, 開口 度 5 度ではこのような加速現象はそれほど顕著ではない . 河川プルームの流動特性から判断すれば, この一時加 速現象は河口付近における水面勾配の急激な変化と淡水 層厚 $H_{u}$ の急減に起因すると考えられる.

\section{4. 考察}

今回の数值実験の実験結果をフルードの相似則に基づ いて淀川洪水流出流への適用を試みよう. 淀川洪水時の 河口水深 $H_{p}$ を $6 \mathrm{~m}$, 河口半幅 $B_{p}$ を $400 \mathrm{~m}$ と仮定し た場合, 数值実験の放流流量 $2 Q_{m}=120.2 \mathrm{~cm}^{3} / \mathrm{sec}$ は量 流 $3400 \mathrm{~m}^{3} / \mathrm{sec}$ になる. これは淀川の 2 年確率の流量に 相当する. この時の開口度の違いによる水位上昇量 $\eta_{0}$ ならびにその差 $\Delta \eta_{0}$ の差は表一1 に示すように求ま る.
表一1 河口における水位上昇

\begin{tabular}{|c|c|c|c|c|}
\hline & 90度 & 30繁 & 11度 & 5 整 \\
\hline$\eta_{1 \prime} \quad \mathrm{cm}$ & 11.13 & 11.36 & 11.42 & 12.26 \\
\hline$I_{7 .} \quad \mathrm{cm}$ & - & 0.23 & 0.29 & 1.14 \\
\hline
\end{tabular}

開口度30度，11度の埋立の場合には河口形状の差異に よる水位上昇の違いは意外と小さい. しかし, 開口度 5 度になると埋立の影響は水位上昇に対して顕著に現れて くる. 但し，建設省河川砂防技術指針（案）で一つの目 安として与えている水位上昇量の $\eta_{0}=H_{0} \Delta \rho / \rho_{s}=13.2$ $\mathrm{cm}$ (単純な静水圧の釣合から算出される) と比較すれ ば，いずれの值も小さい.

以上の考察を総合的に判断すれば，河口開口度が11度 の場合は, 埋立地形の影響が洪水流出流の流動構造に与 える影響は少し認められるものの, 埋立無し（河口開口 度90度）や河口開口度30度と比較して流動構造を変える ほどの影響はない。しかし，河口開口度が 5 度になると， 横方向への拡がりが制限される結果, 洪水流出流の鉛直 方向払がりや断面内流動に対して重大な影響が認められ る. このことから, 埋立造成による河口開口度の変化は 本計算の範囲では開口度11度が一つの目安となる.

最後に本研究は石原藤次郎研究奨学基金ならびに文部 省科学研究費 (重点領域研究 (A), 研究代表者 中辻 啓二 阪大工助教授）の補助を受けたことを記して謝意 を表する.

\section{参 考 文 献}

岸力・板倉忠興 (1985)：洪水時における河口付近の水面形, 第 32 回土木学会論文集, 363 巻, II-4, pp. 145 153.

西田修三(1980)：私信

室田 明・ 中辻啓二・許 再 寧(1989)：大阪湾に抄ける淀川洪 水流の動態に関する数值実験, 海岸工学論文集, 36 巻, pp. $214 \sim 218$.

湯浅楠勝 - 中辻啓二 - 室田 明(1989)：河口二層流の流動構造 の三次元数値実験, 第 44 回土木学会年次学術講演会講演概 要集, II-243, pp. 556 557.

Munk, W.H. and Anderson, E.R.(1948): Notes on a theory of the thermocline, J. Marine Research, Vol. 7, pp. 276 295.

Murota, A., Nakatsuji, K. and Huh, J. Y. (1989): A three dimensional ccmputer simulation of river plume, Refined flow modelling and turbulence measurements, Universal academic Press., pp. 539 547.

Webb, E.K. (1970): Profile relationships: the longliner range and extension to strong stability, Quart. J. R. Met. Soc. Vol. 96 , pp. $67 \sim 90$. 